Acta Technologica Agriculturae 4

Nitra, Slovaca Universitas Agriculturae Nitriae, 2020, pp. 155-160

\title{
EFFECT OF BASIL OIL ON THE PERFORMANCE OF BIODIESEL FUELLED AGRICULTURAL ENGINE
}

\author{
Natesan KAPILAN ${ }^{1 *}$, Rana Pratap REDDY ${ }^{2}$ \\ ${ }^{1}$ Nagarjuna College of Engineering and Technology, Bengaluru, India \\ ${ }^{2}$ Global Academy of Technology, Bengaluru, India
}

The rapidly depleting fossil fuel resources and stringent emission norms have given importance to research of alternative fuels, especially in relation to reduction of greenhouse gases and global warming. In the work presented, biodiesel was derived from honge oil, which is non-edible. The oxidation stability of honge oil biodiesel is low due to the content of unsaturated fatty acids. Therefore, basil oil was used as a natural antioxidant to this biodiesel and the effect of this additive on the engine performance was studied. The addition of basil oil to the honge oil biodiesel increases its oxidation stability thanks to free radical scavenging activities of the basil oil. A set of engine tests was carried out on the agricultural diesel engine with honge oil biodiesel with different concentrations of basil oil. The engine tests showed that the addition of basil oil with the concentration of 1,000 ppm reduces the engine exhaust emissions in contrast to diesel. Basil oil does not have any significant impact on the engine brake thermal efficiency. Based on this work, it is possible to conclude that basil oil can be used as a natural additive to honge oil biodiesel for the purposes of oxidation stability improvement and significant reduction of oxides of nitrogen $\left(\mathrm{NO}_{\mathrm{x}}\right)$ emission.

Keywords: alternative fuel; natural additive; properties; emissions

The industrial growth and globalisation increase the energy demand of the world and the use of fossil fuels for energy production increases carbon dioxide $\left(\mathrm{CO}_{2}\right)$ emissions. Biomass-based energy sources are considered an alternative to fossil fuels and $\mathrm{CO}_{2}$ neutral (Joshi et al., 2017). The majority of recent research works is thus focused on biofuel development and adoption. Biodiesel is a sustainable alternative fuel (Lykova and Gustafsson, 2010). For example, rapeseed oil has significant potential in terms of biodiesel production in Latvia - biofuel production in Latvia was doubled due to demand (Pubule et al., 2011). Hydrocarbon $(\mathrm{HC})$, carbon monoxide (CO) and particulate matter (PM) emissions of the diesel engine can be reduced significantly using biodiesel (Hasan and Rahman, 2017). Viscosity of olive oil is higher than sunflower oil viscosity due to its composition (Hlaváč et al., 2017), which can be reduced by optimising the process variables (Gulum and Bilgin, 2018). Innovative methods developed for the purposes of reduction of water requirements in biodiesel washing (Luna et al., 2014) and energy stimulant methods can be used to reduce energy consumption (Kapilan and Baykov, 2014).

Ginger extract with dosage of $250 \mathrm{ppm}$ can be used as a natural antioxidant for honge oil biodiesel (Devi et al., 2017). Di-tertiary-butyl peroxide and 2-ethylhexyl nitrate additives added to the diesel-biodiesel-pentanol blends with dosage of 1,000 and 2,000 ppm reduce the NO emissions (Imdadul et al., 2017). Synthetic antioxidant propyl gallate (PG) improves the oxidation stability of honge oil biodiesel (Kapilan, 2017). The synthetic antioxidants pose greater risks of side effects (Aburigal et al., 2017), as they may be toxic to the biological systems (Eriotou et al., 2015). Biodiesel fuelled compression ignition engine emits higher amounts of $\mathrm{NO}_{x}$ and various methods are used to reduce the $\mathrm{NO}_{x}$ emission (Khalife et al., 2017). Engine tests conducted with methyl acetate as an additive show that this additive reduces $\mathrm{CO}$ and increases the $\mathrm{NO}_{\mathrm{x}}$ levels (Cakmak et al., 2018). Bio-butanol can be used in diesel engine using cetane number improver (Čedík et al., 2018).

Surface transport of India is dependent on fossil fuel import and hence India's bio-fuel policy stipulates the blending of bio-ethanol and biodiesel with fossil fuel. The non-edible oils are preferred for biodiesel production in India (Biswas and Pohit, 2013). India's fuel demand in the transportation sector may double by 2030 and hence the government of India gives priority to alternative fuels (Leduc et al., 2009). The non-edible oils, such as honge oil, have significant potential for biodiesel production (Patel and Sankhavara, 2017). Honge oil has a considerable potential for biodiesel production in India, however, it has lower oxidation stability and it is necessary to add antioxidants. Basil oil has better antioxidant and antimicrobial activities. Therefore, this work observes utilization of basil oil as a natural antioxidant for honge oil biodiesel and studies the impact of this additive on engine emissions and engine performance. Figs. 1 and 2 show honge tree and honge seeds. Basil (Fig. 3) is an aromatic plant and most widely

Contact address: Natesan Kapilan, Nagarjuna College of Engineering and Technology, Bengaluru, India; e-mail: kapil krecmech@yahoo.com 
used to enhance the aroma and flavour in food. Furthermore, it is also used for medical purposes, because it contains chemical compounds (e.g. linalool, estragole and methyl-cinnamate), which can cure a variety of diseases.

\section{Material and methods}

In this work, non-edible honge oil was used as a feedstock for biodiesel production. The biodiesel was produced by two step transesterification due to higher acid value of the honge oil. Basil oil was used as antioxidant for the honge oil biodiesel $(\mathrm{HOB})$, as the oxidation stability of HOB was low. The basil oil was added with dosages of 1,000 and 2,000 ppm to the HOB. The basil oil completely mixes with the $\mathrm{HOB}$ and the fuel properties of the biodiesel and biodiesel with added basil oil were determined as per the ASTM standards.

Engine tests were performed on a single cylinder agricultural diesel engine and its technical specifications are given in Table 1. The engine speed was measured and indicated by an inductive pickup sensor in conjunction with a digital speed indicator. The engine load was varied using an eddy current dynamometer and the engine experimental setup is shown in Fig. 4. Engine emissions were measured using the AVL emission analyser. Necessary instrumentations were provided to

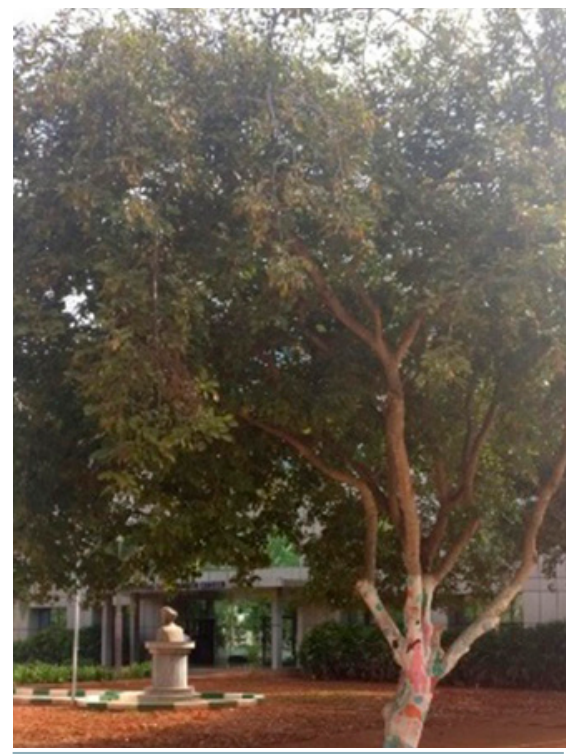

Fig. 1 Honge tree

Table 1
\begin{tabular}{|l||c|}
\hline Engine & Naturally aspirated compression ignition engine \\
\hline Displacement & $661 \mathrm{CC}$ \\
\hline Maximum brake power & $5.2 \mathrm{~kW}$ at $1,500 \mathrm{rpm}$ \\
\hline Compression ratio & $17.5: 1$ \\
\hline Bore and stroke dimension & $87.5 \mathrm{~mm}$ and $110 \mathrm{~mm}$ \\
\hline Fuel injection & direct injection \\
\hline
\end{tabular}

measure the flow rates of fuel and air, and K-type thermocouple was used to measure the exhaust gas temperature (EGT).

\section{Experimental methods}

The engine tests were carried out using diesel as fuel to obtain baseline data. The engine tests were carried out at constant speed. The engine was

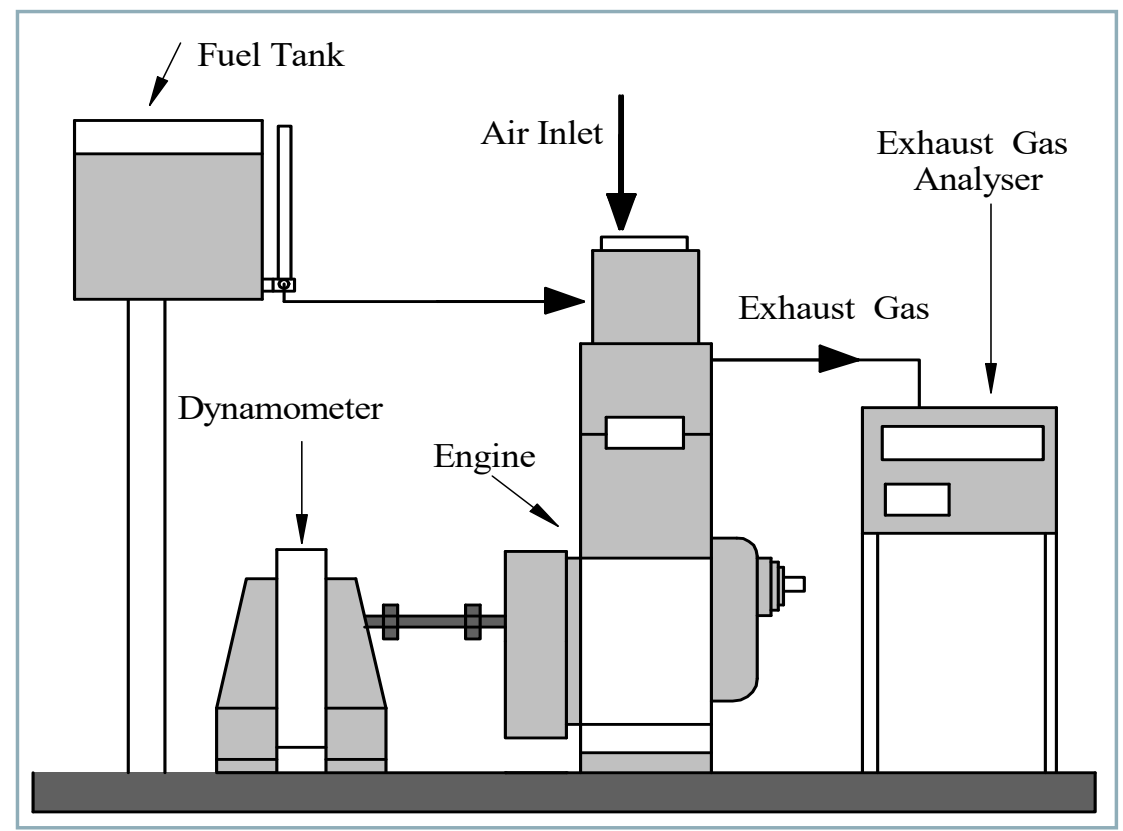

Fig. 4 Engine experimental setup
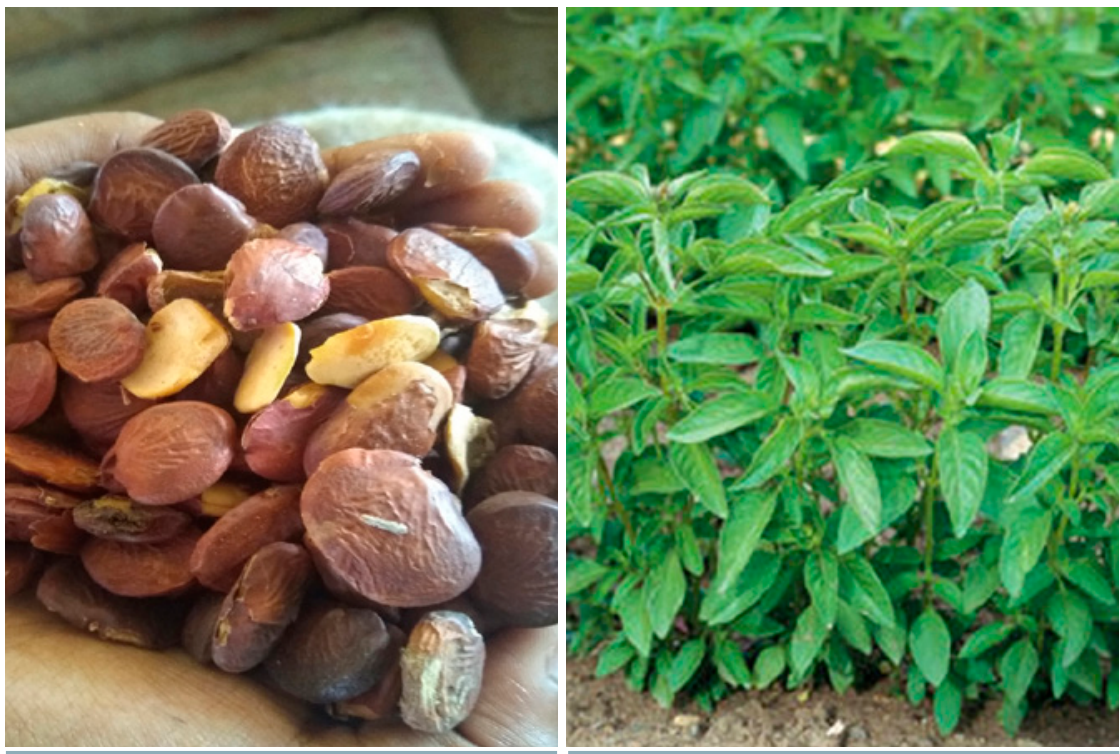

Fig. 2 Honge seeds 
Table 2 Details of the engine exhaust gas analyser

\begin{tabular}{|c|c|c|c|c|}
\hline \multicolumn{5}{|c|}{ Exhaust gas analyser AVL Digas $444 \mathrm{~N}$} \\
\hline Exhaust gas & Principle & Range & Resolution & Uncertainty (\%) \\
\hline co & NDIR & 0 to $2.0 \% \mathrm{vol}$ & $\pm 0.01 \%$ vol & \pm 3 \\
\hline HC & NDIR & 0 to $10,000 \mathrm{ppm}$ & \pm 20 ppm & \pm 2 \\
\hline $\mathrm{NO}_{\mathrm{x}}$ & electrochemical & 0 to $5,000 \mathrm{ppm}$ & $\pm 10 \mathrm{ppm}$ & \pm 2 \\
\hline \multicolumn{5}{|c|}{ Smoke meter AVL 437C } \\
\hline Smoke opacity & & 0 to 100 & \pm 0.1 & \pm 1 \\
\hline
\end{tabular}

started by hand cranking with diesel as fuel and allowed to warm up, the engine load was then increased to $4 \mathrm{~kg}$. After the engine reached steady state condition, engine speed, air flow rate, fuel flow rate and EGT were measured. Gas analyser probe was placed in the engine's exhaust tube to measure and record emission levels. Subsequently, engine load was increased to next load $(8 \mathrm{~kg})$ and observations and emissions were recorded, and similar procedure was followed for other loads. After the engine test, the diesel was drained from the fuel tank and fuel filter. The tank was filled with new fuel, $\mathrm{HOB}$ (B100), and it was allowed to flow in the fuel supply line. The $100 \mathrm{ml}$ of this fuel was collected from the fuel injector to remove the trace of previously used fuel in the fuel line. After this process, the fuel injector was fitted to its original position and engine was started. The engine was allowed to run for 15 min to remove any traces of previously used fuel in the combustion chamber. The important engine observations and emissions were recorded at steady state condition with the new fuel. Previously described procedure was followed for other fuels, such as B1,000 and B2,000.

\section{Results and discussion}

The important properties of the fuels were determined and are shown in Table 3. The properties of HOB with added basil oil are better than those of pure HOB. Fire and flash points of biodiesel with added basil oil are better than those of pure $\mathrm{HOB}$. However, the variation in viscosity and calorific value is small. The addition of basil oil increases the oxidation stability of HOB. Basil oil contains higher amount of linalool and methyl eugenol, which provide better antioxidant activity comparable to synthetic antioxidant BHT (Chenni et al., 2016). Basil oil does not affect copper corrosion value of HOB.
Engine tests were performed with different types of fuels and the impact of basil oil on engine performance and on emissions are discussed below. Engine performance is generally represented by the term brake thermal efficiency (BTE). BTE indicates the effectiveness of conversion of the fuel heat energy into engine shaft power. Fig. 5 shows the impact of basil oil on the engine BTE at various engine loads. BTE was low at part loads due to higher frictional losses; however, it gradually increased as the engine load increased. BTE was high at full engine load. Fig. 5 reveals that the addition of basil oil slightly improved the BTE at higher loads. Basil oil has better volatility in contrast to the biodiesel and thus improved spray formation, which resulted in better premixed combustion phase. BTE of HOB is lower than BTE of diesel, which is due to its higher viscosity and poor volatility. However, $\mathrm{HOB}$ with added basil oil of 1,000 ppm resulted in a slightly higher BTE in comparison to $\mathrm{HOB}$ and $\mathrm{HOB}$ with added basil oil of 2,000 ppm at full load.

Engine combustion temperature affected the EGT. Variation in EGT at different loads is depicted in Fig. 6. The engine consumed higher amount of fuel as the engine load increased. This caused higher combustion temperature and hence the EGT value increased with increase in load. HOB results in higher EGT in contrast to diesel. This is due to higher viscosity and lower volatility of $\mathrm{HOB}$, leading to un-burnt fuels in the premixed combustion phase. This un-burnt fuel burns after the diffusion combustion phase and causes higher EGT. The addition of basil oil to the HOB reduces the EGT, as the basil oil improves the premixed combustion phase. Basil oil dosage of 1,000 ppm results in higher EGT than dosage of 2,000 ppm thanks to better combustion.

The variation of engine's $\mathrm{CO}$ emission at different loads and with various fuels is shown in the Fig. 7. Biodiesel contains oxygen, which enhances the combustion process and results in higher in-cylinder combustion temperature

Table 3

Comparison of fuel properties

\begin{tabular}{|c|c|c|c|c|}
\hline Property & Diesel & Biodiesel & $\mathrm{B} 1,000 \mathrm{ppm}$ & $\mathrm{B} 2,000 \mathrm{ppm}$ \\
\hline Calorific value (MJ.kg ${ }^{-1}$ ) & 42.71 & 39.41 & 39.40 & 39.38 \\
\hline Viscosity at $40^{\circ} \mathrm{C}\left(\mathrm{mm}^{2} \cdot \mathrm{s}^{-1}\right)$ & 2.64 & 3.94 & 3.91 & 3.89 \\
\hline Fire point $\left({ }^{\circ} \mathrm{C}\right)$ & 71 & 161 & 157 & 151 \\
\hline Flash point $\left({ }^{\circ} \mathrm{C}\right)$ & 65 & 130 & 125 & 121 \\
\hline Oxidation stability (h) & - & 3.5 & 6.3 & 7.6 \\
\hline Copper corrosion at $50^{\circ} \mathrm{C}$ for $3 \mathrm{~h}$ & $1 a$ & $1 a$ & $1 a$ & $1 a$ \\
\hline
\end{tabular}




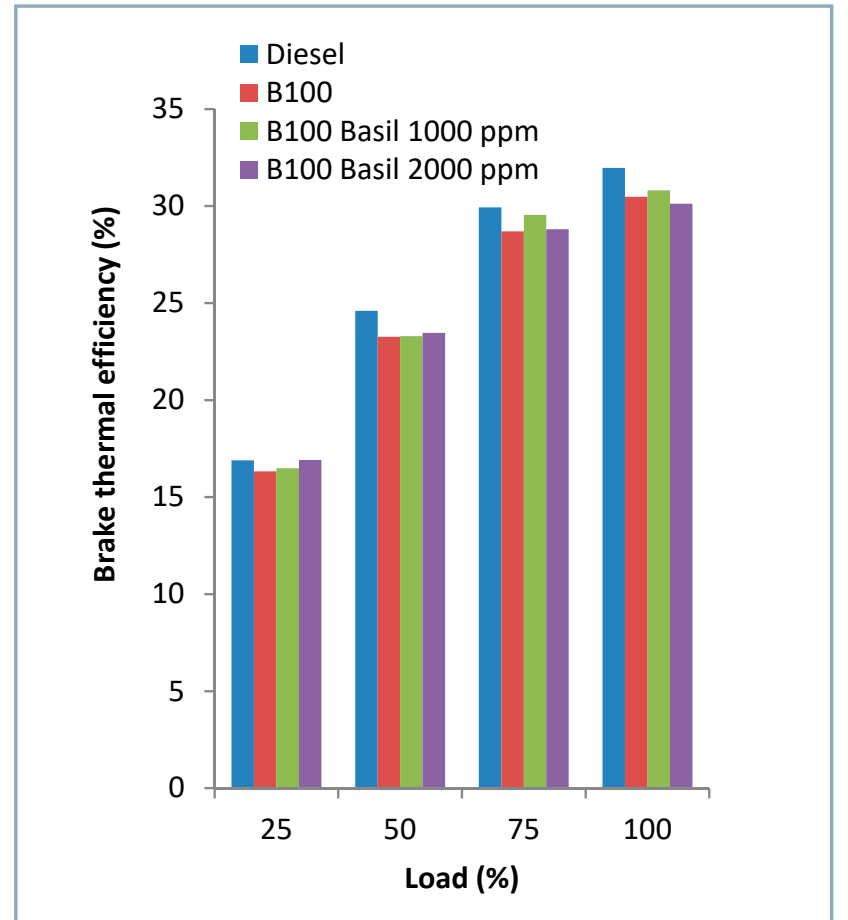

Fig. 5 Variation in BTE at different loads

(Kivevele et al., 2011). HOB thus resulted in lower CO emission in comparison to diesel. However, addition of basil oil to biodiesel increased the CO level. Basil oil shows both antimicrobial and free radical scavenging activities (Eriotou et al., 2015) and the presence of eugenol in its chemical composition provides antioxidant properties (Politeo et al., 2007). Hydrogen peroxide $\left(\mathrm{H}_{2} \mathrm{O}_{2}\right)$ and peroxyl radicals formed during combustion are converted into hydroxyl radicals due to absorption of heat from the combustion chamber. These radicals inhibit CO conversion, leading to an increase in the CO (Palash et al., 2014). However, the CO emission of $\mathrm{HOB}$ with added basil oil is low in contrast to

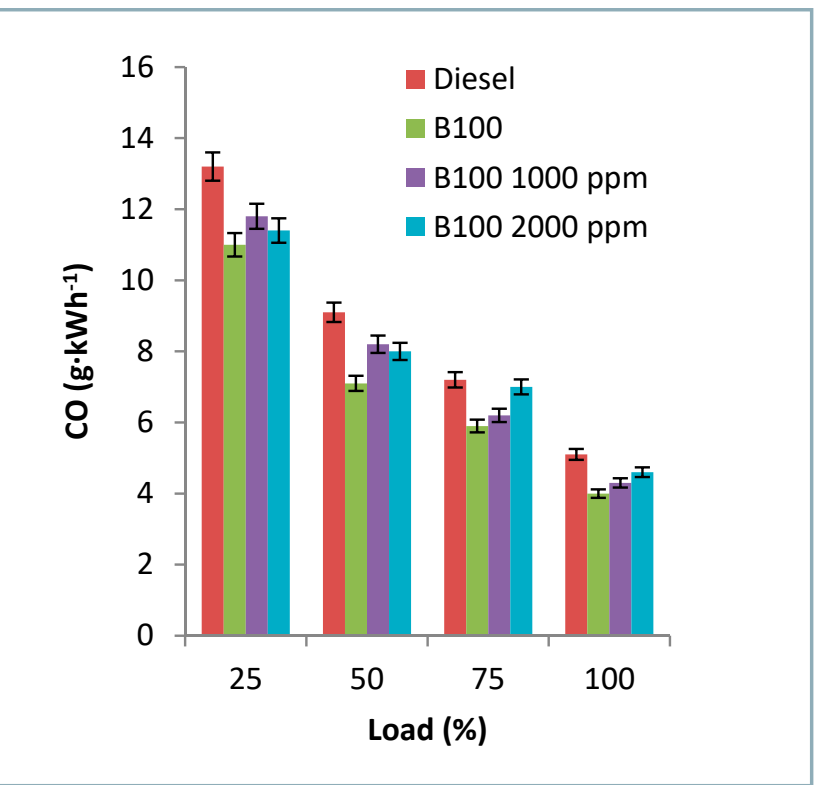

Fig. 7 Variation in $\mathrm{CO}$ at different loads

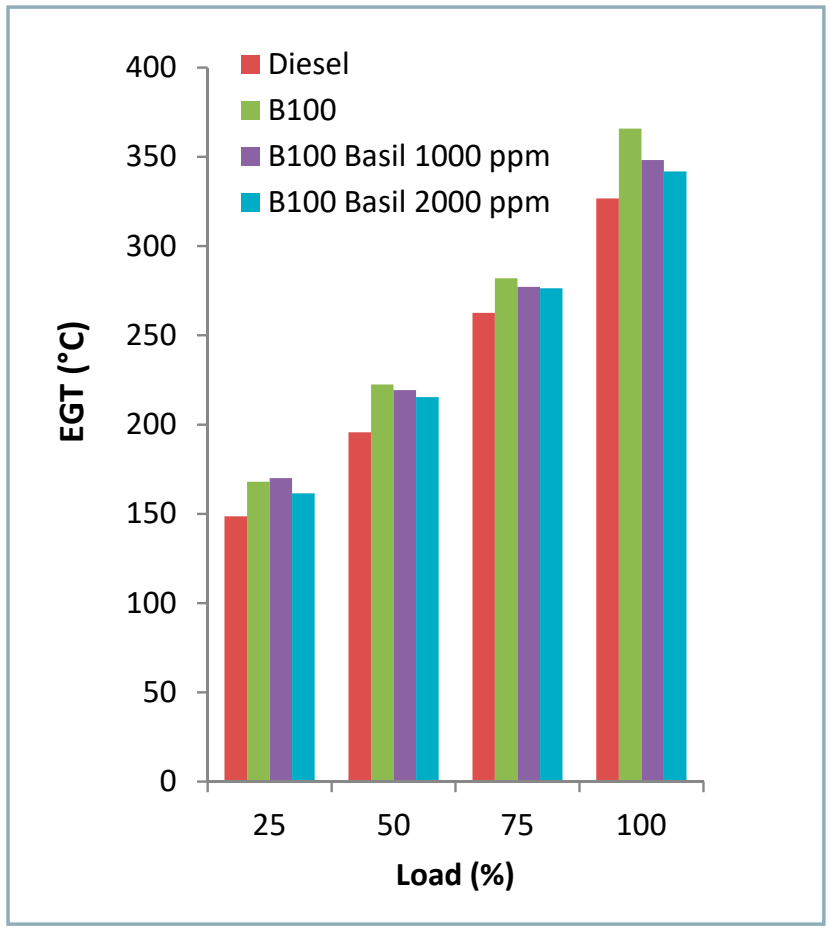

Fig. 6 Variation in EGT at different loads

diesel. The $\mathrm{CO}$ emission of $\mathrm{HOB}$ with 1,000 ppm of basil oil was lower than of $\mathrm{HOB}$ with 2,000 ppm of basil oil. At full load, the HOB CO emission was lower than the diesel $\mathrm{CO}$ emission; the $\mathrm{CO}$ emission of the $\mathrm{HOB}$ with 1,000 ppm basil oil was lower than the diesel $\mathrm{CO}$ emission at full load.

The un-burnt hydrocarbon $(\mathrm{HC})$ emission of the engine depends on the fuel properties; fuel atomization; spray formation; and combustion efficiency. The changes in $\mathrm{HC}$ emission of the engine fuelled with various fuels at different loads is shown in Fig. 8. HOB produced lower HC emission compared to diesel, as biodiesel contains higher concentration of oxygen, which improves flame speed and

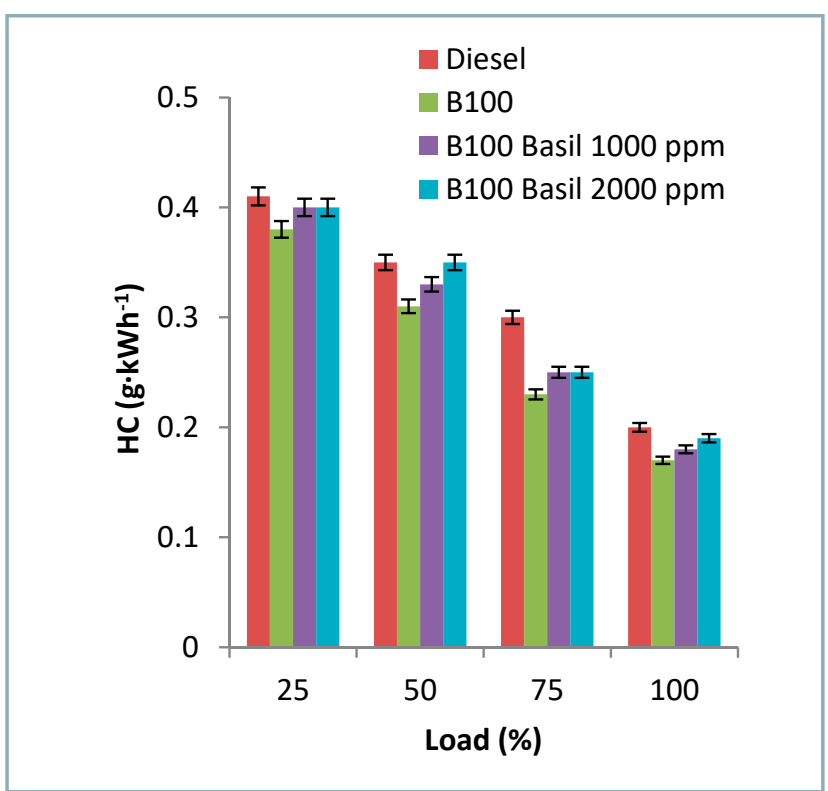

Fig. 8 Variation in $\mathrm{HC}$ at different loads 


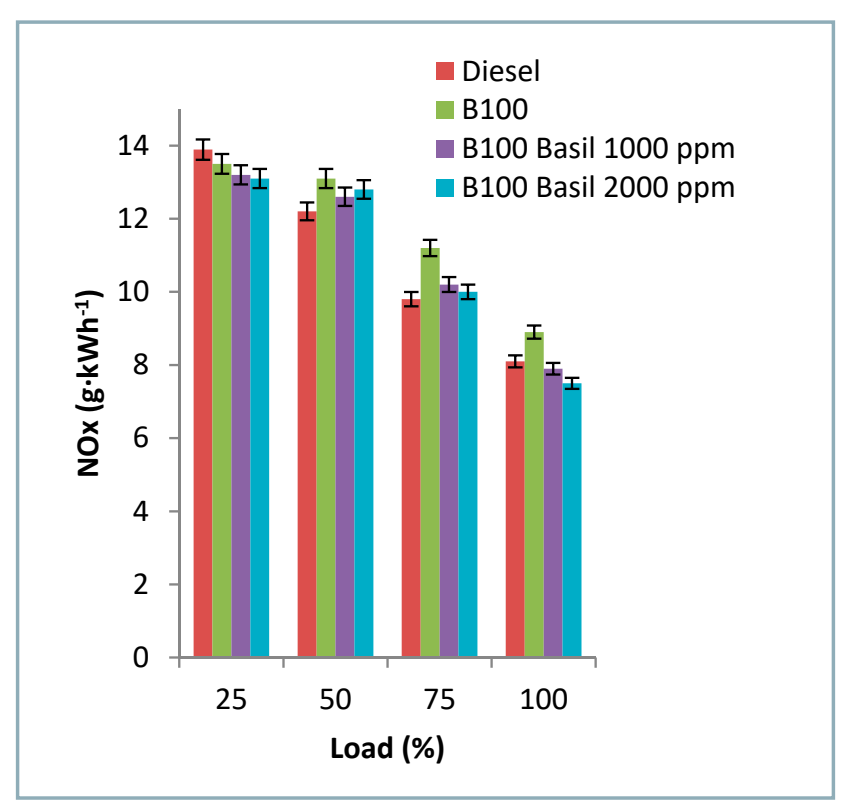

Fig. 9 Variation in $\mathrm{NO}_{x}$ at different loads

enhances the post flame oxidation during air and fuel mixing specifically at fuel rich zones. This causes enhancement of the oxidation of unburnt $\mathrm{HC}$, which reduces $\mathrm{HC}$ emission (Ozsezen et al., 2009). Basil oil increases the engine HC emission due to its free radical scavenging activities. Basil oil with concentration of $1,000 \mathrm{ppm}$ resulted in lower $\mathrm{HC}$ emission compared to concentration of 2,000 ppm due to the lower basil oil quantity, which caused the lower free radical scavenging activity. However, the $\mathrm{HC}$ emission of HOB with 1,000 ppm of basil oil was lower than that of diesel. Similar type of behaviour of the antioxidant was also reported by Varatharajan et al. (2011). Biodiesel with 1,000 ppm resulted in $10 \%$ lower $\mathrm{HC}$ emission than the diesel at full load. The HC emission of HOB was $15 \%$ lower than that of diesel.

The variation in oxides of nitrogen $\left(\mathrm{NO}_{\mathrm{x}}\right)$ at various engine loads with different fuels is shown in Fig. 9. The $\mathrm{NO}_{\mathrm{x}}$ emission is produced due to higher percentage of nitrogen in the air; combustion temperature; and longer presence of fuel inside the combustion chamber. HOB showed higher $\mathrm{NO}_{\mathrm{x}}$ emission than diesel due to presence of oxygen and higher bulk modulus of the HOB, which slightly advanced fuel injection timing and increased the time during which the fuel is present inside the combustion chamber. The addition of 1,000 ppm of basil oil to the biodiesel reduced the $\mathrm{NO}_{\mathrm{x}}$ emission by $7.8 \%$ in contrast to pure $\mathrm{HOB}$. The basil oil contains free-radical scavenging compounds, such as phenolic compounds (Aburigal et al., 2017), that are excellent hydrogen donors and react with the species of reactive nitrogen and reactive oxygen. This termination reaction breaks new radical formation (Pereira et al., 2009).

Fig. 10 depicts the impacts of different fuels on the engine smoke opacity at various loads. Smoke emission indicates the visible part of poor combustion of the fuel burnt in combustion chamber. HOB produced smoke emission lower by $14 \%$ than diesel, since the biodiesel is oxygenated. HOB with 2,000 ppm of basil oil showed higher smoke emission in contrast to $\mathrm{HOB}$ with 1,000 ppm

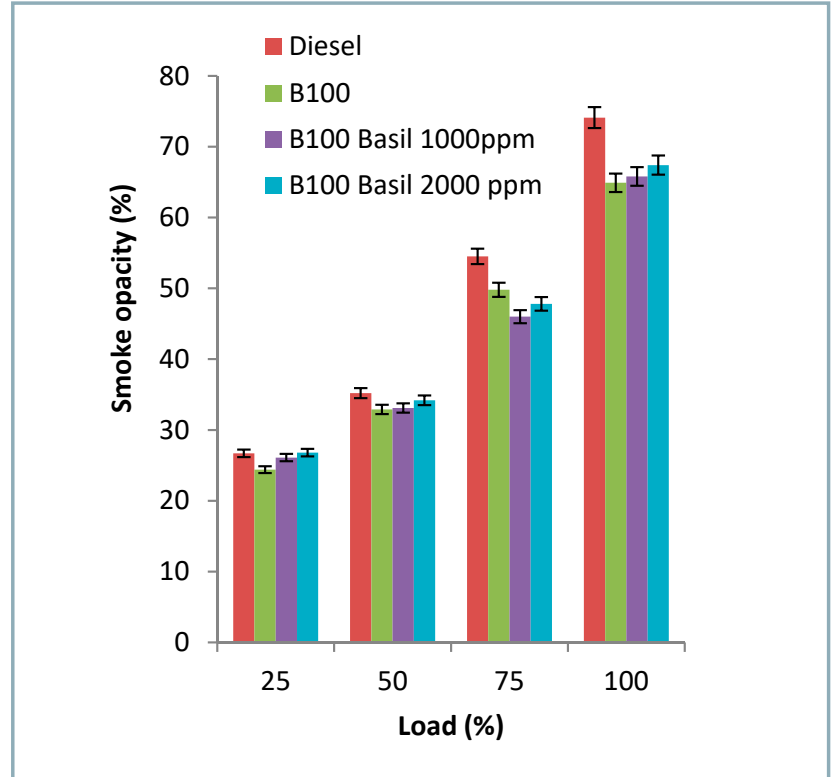

Fig. 10 Variation in smoke level at different loads

of basil oil. The addition of basil oil to the HOB increases the smoke emission because basil oil additive promotes reductive reactions inhibiting oxidative reactions (Wang et al., 2014). It is suggested that basil oil contains a phenolic compound with ability to scavenge the alkylperoxyl radical. The smoke emission of HOB with 1,000 ppm of basil oil was lower compared to diesel. However, a slight variation was observed between $\mathrm{HOB}$ with 2,000 ppm of basil oil and diesel and this behaviour is similar to observations reported by Khatib et al. (2018).

\section{Conclusion}

Honge oil biodiesel contains unsaturated components, which result in lower oxidation stability. This issue can be improved by addition of basil oil to the biodiesel, thus enhancing its oxidation stability. The major emission of the agricultural diesel engine fuelled by biodiesel is $\mathrm{NO}_{\mathrm{x}}$ emission. The addition of basil oil to the HOB significantly affects the engine $\mathrm{NO}_{\mathrm{x}}$ emission. However, basil oil increases exhaust emissions, such as $\mathrm{CO}, \mathrm{HC}$ and smoke, due to its free radical scavenging activities that reduce oxidation and inhibit fuel combustion. Nevertheless, these emission values are lower than those showed by fossil diesel. The addition of basil oil to the HOB does not have a significant impact on engine thermal efficiency. Basil oil dosage of 1,000 ppm resulted in lower $\mathrm{CO}, \mathrm{HC}$ and smoke emissions and slightly higher BTE compared to basil oil dosage of 2,000 ppm. $\mathrm{NO}_{\mathrm{x}}$ emission reduction with basil oil dosage of $1,000 \mathrm{ppm}$ at full load was $11.2 \%$ in contrast to the B100. Based on this work, it is possible to conclude that basil oil can be used as an antioxidant for the $\mathrm{HOB}$, significantly reducing $\mathrm{NO}_{\mathrm{x}}$ emission.

\section{Acknowledgments}

Authors express their gratitude to VTU for funding this project (Aca. /2013-14 / A-9/63). 


\section{References}

ABURIGAL, Y. A. A. - MIRGHANI, M. E. S. - ELMOGTABA, E. Y. - SIRIBLE, A. A. M. - HAMZA, N. B. - HUSSEIN, I. H. 2017. Total phenolic content and antioxidant capacity of basil (Ocimum basilicum L.) leaves from different locations. In International Food Research Journal, vol. 24, pp. 378-381.

BISWAS, P. K. - POHIT, S. 2013. What ails India's biodiesel programme? In Energy Policy, vol. 52, pp. 789-796.

CAKMAK, A. - KAPUSUZ, M. - GANIYEV, O. - OZCAN, H. 2018. Effects of methyl acetate as oxygenated fuel blending on performance and emissions of $\mathrm{SI}$ engine. In Environmental and Climate Technologies, vol. 22, no. 1, pp. 55-68.

ČEDÍK, J. - PEXA, M. - PETERKA, B. - HOLŮBEK, M. - MADER, D. PRAŽAN, R. 2018. Effect of biobutanol-sunflower oil-diesel fuel blends on combustion characteristics of compression ignition engine. In Acta Technologica Agriculturae, vol. 21, no. 4, pp. 130-135.

DEVI, A. - DAS, V. K. - DEKA, D. 2017. Ginger extract as a nature based robust additive and its influence on the oxidation stability of biodiesel synthesized from non-edible oil. In Fuel, vol. 187, pp. 306-314.

ERIOTOU, E. - ANASTASIADOU, K. - NIKOLOPOULOS, D. KOULOUGLIOTIS, D. 2015. Antimicrobial and free radical scavenging activities of basil (Ocimum basilicum) essential oil isolated from five plant varieties growing in Greece. In Journal of Nutrition \& Food Sciences, vol. 5, no. 3, pp. 1-9.

GULUM, M. - BILGIN, A. 2018. An experimental optimization research of methyl and ethyl esters production from safflower oil. In Environmental and Climate Technologies, vol. 22, no. 1, pp. 132-148.

HASAN, M. - RAHMAN, M. 2017. Performance and emission characteristics of biodiesel-diesel blend and environmental and economic impacts of biodiesel production: A review. In Renewable and Sustainable Energy Reviews, vol. 74, pp. 938-948.

HLAVÁČ, P. - BOŽIKOVÁ, M. - PETROVIĆ, A. 2017. Selected physical properties assessment of sunflower and olive oils. In Acta Technologica Agriculturae, vol. 22, no. 3, pp. 86-91.

CHENNI, M. - EL ABED, D. - RAKOTOMANOMANA, N. - FERNANDEZ, X. - CHEMAT, F. 2016. Comparative study of essential oils extracted from Egyptian basil leaves (Ocimum basilicum L.) using hydrodistillation and solvent-free microwave extraction. In Molecules, vol. 21, no. 1, pp. 113-118.

IMDADUL, H. - RASHED, M. - SHAHIN, M. - MASJUKI, H. - KALAM, M. KAMRUZZAMAN, M. - RASHEDUL, H. 2017. Quality improvement of biodiesel blends using different promising fuel additives to reduce fuel consumption and $\mathrm{NO}$ emission from $\mathrm{Cl}$ engine. In Energy Conversion and Management, vol. 138, pp. 327-337.

JOSHI, G. - PANDEY, J. K. - RANA, S. - RAWAT, D. S. 2017. Challenges and opportunities for the application of biofuel. In Renewable and Sustainable Energy Reviews, vol. 79, pp. 850-866.

KAPILAN, N. - BAYKOV, B. D. 2014. A review on new methods used for the production of biodiesel. In Petroleum \& Coal, vol. 56, no. 1, pp. 62-73.

KAPILAN, N. 2017. Studies on effect of antioxidant on the performance of biodiesel operated diesel engine. In Journal of Sustainable Energy Engineering, vol. 5, no. 1, pp. 3-12.
KHALIFE, E. - TABATABAEI, M. - DEMIRBAS, A. - AGHBASHLO, M. 2017. Impacts of additives on performance and emission characteristics of diesel engines during steady state operation. In Progress in Energy and Combustion Science, vol. 59, pp. 32-78.

KHATIB, S. - HARNAFI, M. - TOUISS, I. - BEKKOUCH, O. - AMRANI, S. HARNAFI, H. 2018. Phenolic extract of basil prevents lipid oxidation in sunflower oil, beef and turkey meat: A comparison with synthetic antioxidant BHA. In American Journal of Food Science and Nutrition, vol. 5, no. 3, pp. 66-75.

KIVEVELE, T. T. - KRISTÓF, L. - BERECZKY, Á - MBARAWA, M. M. 2011. Engine performance, exhaust emissions and combustion characteristics of a $\mathrm{Cl}$ engine fuelled with croton megalocarpus methyl ester with antioxidant. In Fuel, vol. 90, no. 8, pp. 2782-2789. LEDUC, S. - NATARAJAN, K. - DOTZAUER, E. - MCCALLUM, I. OBERSTEINER, M. 2009. Optimizing biodiesel production in India. In Applied Energy, vol. 86, pp. 145-153.

LUNA, D. - CALERO, J. - SANCHO, E. - LUNA, C. - POSADILLO, A. - BAUTISTA - VERDUGO, C. 2014. Technological challenges for the production of biodiesel in arid lands. In Journal of Arid Environments, vol. 102, pp. 127-138.

LYKOVA, N. - GUSTAFSSON, J. E. 2010. A survey of biofuel production potentials in Russia. In Scientific Journal of Riga Technical University: Environmental and Climate Technologies, vol. 4, no. 1, pp. 64-75.

OZSEZEN, A. N. - CANAKCI, M. - TURKCAN, A. - SAYIN, C. 2009. Performance and combustion characteristics of a DI diesel engine fuelled with waste palm oil and canola oil methyl esters. In Fuel, vol. 88, no. 4, pp. 629-636.

PALASH, S. - KALAM, M. - MASJUKI, H. - ARBAB, M. - MASUM, B. SANJID, A. 2014. Impacts of $\mathrm{NO}_{x}$ reducing antioxidant additive on performance and emissions of a multi-cylinder diesel engine fuelled with Jatropha biodiesel blends. In Energy Conversion and Management, vol. 77, pp. 577-585.

PATEL, R. L. - SANKHAVARA, C. 2017. Biodiesel production from Karanja oil and its use in diesel engine: A review. In Renewable and Sustainable Energy Reviews, vol. 71, pp. 464-474.

PEREIRA, D. - VALENTÃO, P. - PEREIRA, J. - ANDRADE, P. 2009. Phenolics: From chemistry to biology. In Molecules, vol. 14, pp. 2202-2211.

POLITEO, O. - JUKIC, M. - MILOS, M. 2007. Chemical composition and antioxidant capacity of free volatile aglycones from basil (Ocimum basilicum L.) compared with its essential oil. In Food Chemistry, vol. 101, no. 1, pp. 379-385.

PUBULE, J. - ROMAGNOLI, F. - BLUMBERGA, D. 2011. Why biodiesel is environmentally better than traditional, fossil-based diesel: An LCA approach. In Environmental and Climate Technologies, vol. 7, no. 1, pp. 93-99.

VARATHARAJAN, K. - CHERALATHAN, M. - VELRAJ, R. 2011. Mitigation of $\mathrm{NO}_{x}$ emissions from a Jatropha biodiesel fuelled $\mathrm{DI}$ diesel engine using antioxidant additives. In Fuel, vol. 90, no. 8, pp. 2721-2725.

WANG, Z. - WU, J. - MAO, G. - QU, L. - WANG, F. - HU, H. 2014. Effect of antioxidants on emission of biodiesel. In the Transactions of the Chinese Society of Agricultural Engineering, vol. 30, pp. 266-271. 